УДК 796.01+378:159.9

DOI https://doi.org/10.26661/2663-5925-2021-3-14

\title{
ПСИХОЛОГІЧНІ ОСОБЛИВОСТІ СХИЛЬНОСТІ ДО СПОРТИВНӦ̈ ДІЯЛЬНОСТІ (НА ПРИКЛАДІ СПОРТСМЕНІВ-ДЗЮДОЇСТІВ)
}

\author{
Михайлов Р. В. \\ майстер спорту з дзюдо, чемпіон світу серед майстрів, \\ чемпіон Свропи серед майстрів, чемпіон Украӥни, \\ спеціаліст \\ Навчально-науковий інститут «Фінансова академія» \\ Університету митної справи та фінансів \\ вул. Володимира Вернадського (Дзержинського), 2/4, Дніпро, Украӥна \\ orcid.org/0000-0001-8523-1729 \\ Judoippon777@gmail.com
}

\begin{abstract}
Ключові слова: дзюдо, спортсмени-дзюдоїсти, темперамент, схильність до спортивної діяльності, психологічна підготовка спортсменів-дзюдоїстів.
\end{abstract}

У статті наведено результати дослідження особливостей темпераменту та емоційної експресії як вроджено зумовлених рис, що притаманні спортсменам-дзюдоїстам та чинять принциповий вплив на спортивний успіх і високі досягнення у дзюдо. Початкове дослідження психологічних схильностей спортсменів до дзюдо проводилося 3 визначення особливостей темпераменту досліджуваних; була використана методика Стреляу, що базується на регулятивній теорії темпераменту та показує основні параметри сили, врівноваженості, рухливості, лабільності та ригідності нервової системи. Наведено результати порівняльного аналізу спортсменів-професіоналів та любителівдзюдоїстів. У спортсменів-дзюдоїстів більш виражені показники сили процесів збудження, гальмування та рухливості нервових процесів, аніж у любителів. У досліджуваних спортсменів-дзюдоїстів сила процесів гальмування домінує над слабкістю гальмування. Зокрема, у спортсменів-дзюдоїстів показники сили процесів гальмування більш виражені, ніж у спортсменів-любителів. Також у досліджуваних спортсменів-дзюдоїстів показник рухливості нервових процесів є значно більш домінуючим порівняно зі спортсменами-любителями. Визначено основні закономірності психологічної стилістики реагування, що властиві тим чи іншим типам темпераменту досліджуваних. Найбільш вираженими в розрізі оптимальності емоційного реагування по групі спортсменів-любителів $є$ шкали міміки, темпу мовлення, збою мовлення, інтонації. Низькі результати отримано за шкалами «зайві рухи», «рухова активність», «образність мовлення» та «недиференційовані емоційні прояви». Поряд із цим можемо констатувати, що аналогічні показники по групі спортсменів-дзюдоїстів є дещо вищими, що, ймовірно, говорить про більш адекватне емоційне реагування спортсменів-професіоналів, тоді як для любителів даний аспект є дещо вторинним (посилаючись на професійну діяльність). На основі отриманих результатів описано можливості психологічної роботи зі спортсменами залежно від їніх психічних можливостей та вроджених темпераментальних рис особистості спортсмена-дзюдоїста. 


\title{
PSYCHOLOGICAL CHARACTERISTICS OF THE PROPENSITY FOR SPORTS ACTIVITY (ON THE EXAMPLE OF JUDO ATHLETES)
}

\author{
Mykhailov R. V. \\ Master of Sports in Judo, World Champion among Masters, \\ Champion of Europe among Masters, Champion of Ukraine, \\ Specialist \\ Educational Research Institute "Finance Academy" of the University of Customs and Finance \\ Vladimir Vernadsky (Dzerzhinsky) str., 2/4, Dnipro, Ukraine \\ orcid.org/0000-0001-8523-1729 \\ Judoippon777@gmail.com
}

Key words: judo, judo athletes, temperament, inclination for sports activities, psychological training of judo athletes.
The article presents the results of the study of the features of temperament and emotional expression as innate features inherent in judo athletes and have a fundamental influence on sports success and high achievement in judo. The initial study of psychological inclinations of judo athletes was conducted by determining the characteristics of the subjects' temperament; the Strelau method based on the regulatory theory of temperament was used and shows the main parameters of strength, equilibrium, mobility, lability, and rigidity of the nervous system. The results of comparative analysis of professional and amateur judo athletes are presented. Judo sportsmen have more expressed indexes of power of processes of excitation, inhibition, and mobility of nervous processes than amateurs. In the studied judo athletes, the strength of inhibition processes dominates over the weakness of inhibition. In particular, in judo athletes the indicators of the power of inhibition processes are more pronounced than in amateur athletes. Also, in the studied sportsmen - judoists the index of mobility of nervous processes is much more dominant in comparison with the sportsmen - amateurs. The main regularities of the psychological stylistics of the reaction, inherent in those or other types of temperament of the subjects are determined. The scales of facial expressions, speech tempo, speech failure, intonation are the most pronounced in the context of the optimality of emotional response in the group of amateur athletes. Low results were obtained on scales of superfluous movements, motor activity, figurativeness of speech and undifferentiated emotional manifestations. Along with this we can state that similar indicators on the group of sportsmen - judoists are somewhat higher, probably speaking about more adequate emotional reactions of sportsmenprofessionals, while for amateurs this aspect is somewhat secondary (referring to the professional activity). On the basis of the received results opportunities of psychological work with sportsmen depending on mental opportunities and innate temperamental features of the personality of the judoist sportsman are described.
Постановка проблеми. Специфічними рисами будь-якого типу спортивної діяльності є психологічна зумовленість рис темпераменту та характеру особистості спортсмена. Загальновідомо, що найбільш успішним у спортивних досягненнях $€$ такий тип особистості, риси якого найбільш точно відповідають спортивно зумовленим саме в даному виді занять. Залежно від навиків, якими володіє професіонал у певному виді спорту, та ступеня складності розвитку цих навиків говорять про схильність тієї чи іншої особи до реалізації певного виду спортивної діяльності, зокрема, i на рівні високої успішності. При цьому психологічна схильність тісно сплітається із психофізичною, тому коли аналізується ступінь успішності спортсмена, переважно йдеться лише про навички, а не про психологічну схильність до їх маніфестування та актуалізацію проявів як таких.

У межах нашого дослідження підкреслено провідну роль саме темпераментального (вродженого) складника психологічного портрету успішного спортсмена-професіонала. На прикладі спортсменів-дзюдоїстів, з якими протягом багатьох років тісно співпрацює автор статті, проаналізуємо 
характерні особливості професіоналів спортивного дзюдо, їхні провідні риси емоційного реагування, темпераменту та невербальних проявів, які доказово $є$ вагомими чинниками впливу на схильність до успішності у професійному спорті.

Аналіз останніх досліджень і публікацій. Аналіз психологічних особливостей схильності до спортивної діяльності є предметом детального наукового інтересу [1-6]. Основними науковими працями, на які ми спираємося в дослідженні, $е$ роботи науковців, які вивчали психологічні особливості спортивної мотивації: М. Алдерман, М. Алексєєва, Р. Десі, С. Занюк, А. Маркова, А. Маслоу, Т. Матис, М. Матюхіна, С. Москвичов, А. Орлов, В. Рибалка, Б. Розен, Х. Хекхаузен, П. Якобсон та ін.

Багато досліджень присвячено вивченню мотивації досягнення спортивного успіху (Дж. Аткінсон, Б. Вайнер, К. Двек, Д. Макклелланд, Дж. Роттер, Ф. Хайдер та ін.). Зазначені дослідження є досить вагомим внеском у психологічну теорію. Проте ступінь дослідженості психологічних засад організації процесу навчання та формування мотивації досягнення успіху в спортивно обдарованої молоді дотепер не були предметом спеціального наукового вивчення.

Мета статті - виявити основні взаємозв'язки особливостей темпераменту та психологічної схильності спортсменів-дзюдоїстів до спортивної діяльності.

Виклад основного матеріалу. Дослідження психологічних рис спортсменів-дзюдоїстів та рівнів професіоналів і любителів відбувалося протягом кількох місяців, протягом низького сезону підготовки до змагань, щоб чинники втоми та інші фактори не впливали на валідність та надійність даних експериментів. Робота проводилася зі спортсменами Федерації дзюдо Києва (48 осіб) і зі спортсменами-любителями, які працюють на базі ДЮСШ м. Києва. Середній вік учасників становить 19,5 років (дорослі спортсмени).

Початкове дослідження психологічних схильностей спортсменів до дзюдо проводилося з визначення особливостей темпераменту досліджуваних. Було використано розповсюджену та досить репрезентативну методику Я. Стреляу (PTS), що базується на регулятивній теорії темпераменту та показує основні параметри сили, врівноваженості, рухливості, лабільності та ригідності нервової системи. Для зручності та наочності сприйняття результати наведено у вигляді діаграм, було використано порівняльний аналіз груп і здійснено відповідний розподіл. Отримані результати для зручності представимо наочно і проаналізуємо окремо кожну шкалу. Первинно представимо дані по рівнях вираженості процесів збудження і гальмування за методикою Стреляу (рис. 1-2).

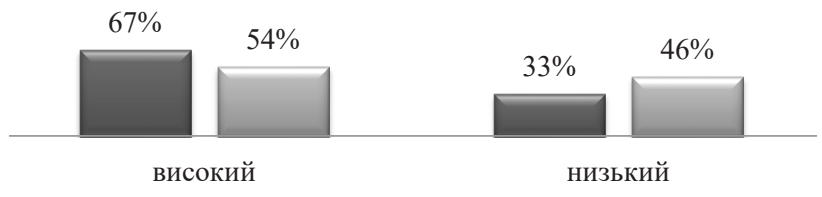

\section{Рис. 1. Рівні вираженості процесів збудження у структурі темпераменту досліджуваних}

У спортсменів-дзюдоїстів більш виражені показники сили процесів збудження, гальмування та рухливості нервових процесів, аніж у любителів. Як видно з даних, рівень процесів збудження $\epsilon$ домінуючим по силі у спортсменів-дзюдоїстів: 67\% у професійних спортсменів та $54 \%$ у любителів. Слабкість процесів збудження відзначено в більшій мірі у любителів: 33\% досліджуваних спортсменів-професіоналів та 46\% досліджуваних любителів мають виражену слабкість процесів збудження.

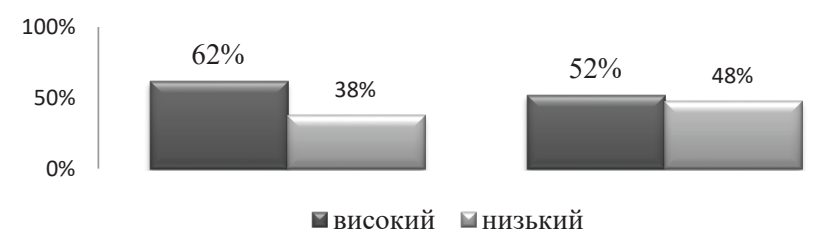

Рис. 2. Рівні вираженості процесів гальмування у структурі темпераменту досліджуваних

У досліджуваних спортсменів-дзюдоїстів сила процесів гальмування домінує над слабкістю гальмування. Зокрема, у спортсменів-дзюдоїстів показники сили процесів гальмування більш виражені, ніж у спортсменів-любителів (62\% у спортсменів-професіоналів та $52 \%$ у любителів). Одночасно показники слабкості процесів гальмування у спортсменів-любителів становлять $48 \%$, а у професіоналів - 38\%.

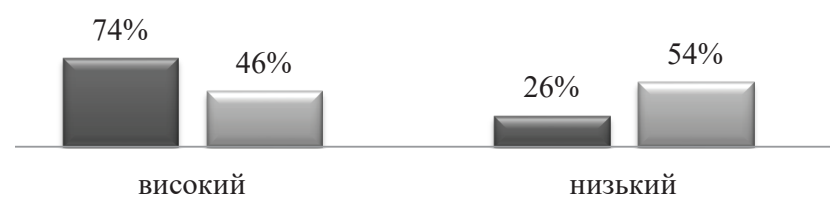

Рис. 3. Рівні вираженості рухливості нервових процесів у структурі темпераменту досліджуваних

Також у досліджуваних спортсменів-дзюдоїстів показник рухливості нервових процесів $€$ значно більш домінуючим порівняно зі спортсменами-любителями: 74\% у професіоналів та 46\% у любителів. Відповідно, у любителів-дзюдоїстів більш виражена слабкість даного показника, тобто інертність нервових процесів. Так, інертність нервових процесів виражена у $26 \%$ спортсменів-дзюдоїстів та у 54\% спортсменів-любителів. 
Показник оптимуму врівноваженості знаходиться в межах 0,85-1,15. Показники, що мають меншу вираженість (менше 0,85), позначають неврівноваженість у бік гальмування (тобто процеси збудження домінують над процесами гальмування); показники, які отримали кількісну вираженість більше 1,15 , позначають неврівноваженість у бік збудження (тобто процеси гальмування домінують над процесами збудження). Із представлених результатів видно, що в досліджуваних спортсменів-дзюдоїстів оптимум врівноваженості виражений значно більше, аніж у любителів. Домінуючим у любителів-дзюдоїстів $\epsilon$ процес неврівноваженості у бік збудження, тобто процеси гальмування в їхному темпераменті $\epsilon$ домінуючими.

Отже, підсумуємо, що у спортсменів-дзюдоїстів порівняно з любителями дзюдо більш виражені показники сили процесів збудження, сили процесів гальмування та рухливості нервових процесів; також у спортсменів-професіоналів більш виражена врівноваженість по силі темпераменту (вищі показники оптимуму врівноваженості). Поряд із цим у любителів-дзюдоїстів більш виражені показники слабкості процесів збудження, слабкості процесів гальмування та інертності нервових процесів; врівноваженість по силі темпераменту переважає в бік збудження.

Проаналізуємо специфіку невербальної комунікації досліджуваних спортсменів-дзюдоїстів за методикою «Опитувальник емоційної експресії» Л.Є. Богіної та анкетним опитувальником, розробленим автором. Згідно з результатами, отриманими за опитувальником емоційної експресії (OEЕ), вдалося визначити специфіку невербальних проявів емоцій у досліджуваних спортсменів-дзюдоїстів (табл. 2).

Представлені результати позначаються за двома полюсними критеріями «високий рівень» та «низький рівень», що позначають відповідно оптимальну вираженість представленої ознаки та iï неадекватну вираженість.

Як видно $з$ даних, показники емоційно експресивних рис виражені у спортсменів-дзюдоїстів досить оптимально. Зокрема, найбільш якісними виявилися показники за шкалами міміки $(84 \%)$, інтонації (77\%), образності мовлення (74\%), темпу мовлення (62\%) тощо. Поряд із цим найменшу вираженість отримали результати за такими шкалами: зайві рухи (16\%), збій мовлення (22\%), недиференційовані емоційні прояви (12\%).

Отриманий розподіл за шкалами показує, що найбільш вираженими (в розрізі оптимальності емоційного реагування) по групі любителів є такі шкали: міміка (54\%), темп мовлення (64\%), збій мовлення (44\%), інтонація (42\%). Низькі результати отримано за шкалами: зайві рухи $(23 \%)$, рухова активність (32\%), образність мовлення (33\%) та недиференційовані емоційні прояви (32\%). Поряд із цим можемо констатувати, що

Таблиця 1

Врівноваженість по силі темпераменту досліджуваних, за додатковим показником методики Я. Стреляу

\begin{tabular}{|c|l|c|c|}
\hline № п/п & \multicolumn{1}{|c|}{ Критерії врівноваженості по силі } & Професіонали & Любителі \\
\hline 1 & Врівноваженість (оптимум) & $54 \%$ & $34 \%$ \\
\hline 2 & Неврівноваженість у бік гальмування & $21 \%$ & $27 \%$ \\
\hline 3 & Неврівноваженість у бік збудження & $25 \%$ & $39 \%$ \\
\hline
\end{tabular}

Таблиця 2

Компоненти емоційної експресії, за методикою Л.Є. Богіної

\begin{tabular}{|c|l|c|c|c|c|}
\hline \multirow{2}{*}{$№$ п/пп Ш } & \multirow{2}{*}{ Шкали емоційної експресії } & \multicolumn{2}{|c|}{ Спортсмени-дзюдоїсти } & \multicolumn{2}{|c|}{ Любителі } \\
\cline { 3 - 5 } & & високий рівень & низький рівень & високий рівень & низький рівень \\
\hline 1 & Гучність голосу & $42 \%$ & $58 \%$ & $37 \%$ & $63 \%$ \\
\hline 2 & Темп мовлення & $62 \%$ & $38 \%$ & $64 \%$ & $36 \%$ \\
\hline 3 & Образність мовлення & $74 \%$ & $26 \%$ & $33 \%$ & $67 \%$ \\
\hline 4 & Збій мовлення & $22 \%$ & $78 \%$ & $44 \%$ & $56 \%$ \\
\hline 5 & Інтонація & $77 \%$ & $23 \%$ & $42 \%$ & $58 \%$ \\
\hline 6 & Рухова активність & $52 \%$ & $48 \%$ & $32 \%$ & $68 \%$ \\
\hline 7 & Зайві рухи & $16 \%$ & $84 \%$ & $23 \%$ & $77 \%$ \\
\hline 8 & Міміка & $84 \%$ & $16 \%$ & $54 \%$ & $46 \%$ \\
\hline 9 & $\begin{array}{l}\text { Не диференційована по } \\
\text { шкалах експресія }\end{array}$ & $12 \%$ & $88 \%$ & $32 \%$ & $68 \%$ \\
\hline
\end{tabular}




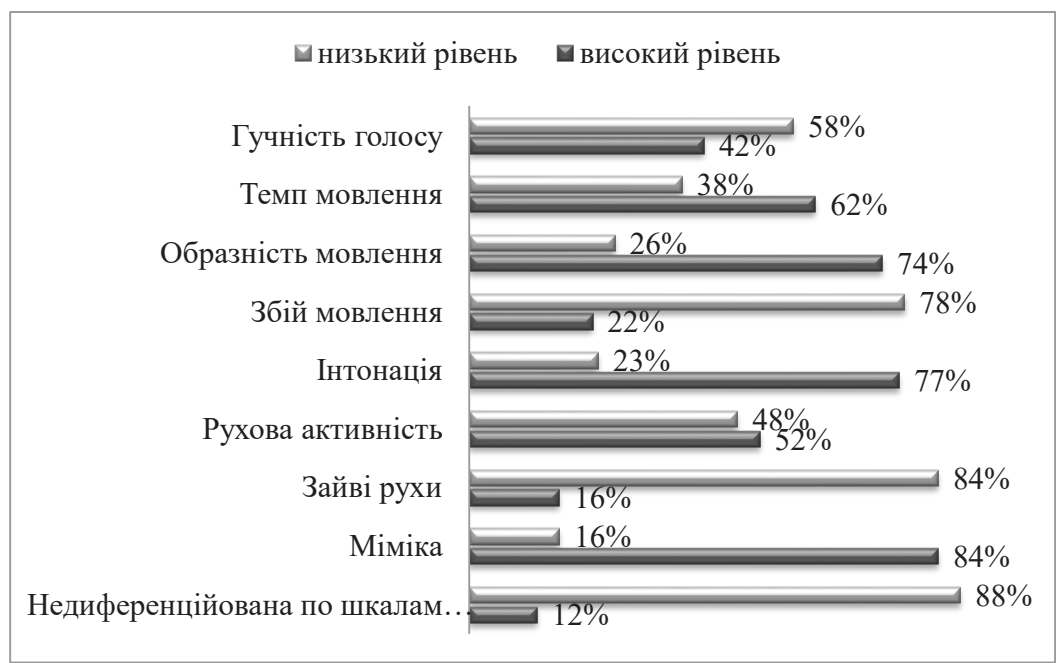

Рис. 4. Компоненти емоційної експресії (за методикою ОЕЕ Л.Є. Богіної) досліджуваних спортсменів-дзюдоїстів

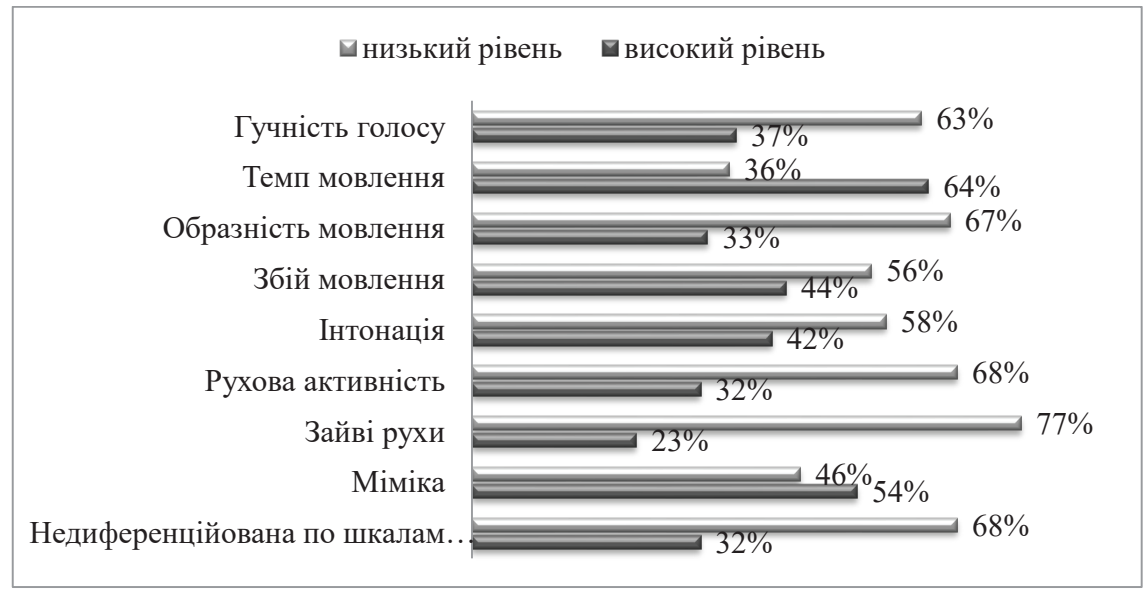
Рис. 5. Компоненти емоційної експресії (за методикою ОЕЕ Л.С. Богіної)
досліджуваних дзюдоїстів-любителів

аналогічні показники по групі спортсменів-дзюдоїстів є дещо вищими, що, ймовірно, говорить про більш адекватне емоційне реагування спортсменів-професіоналів, тоді як для любителів даний аспект є дещо вторинним (посилаючись на професійну діяльність).

Розроблена нами анкета дала змогу виявити три компоненти невербального спілкування: когнітивний, емоційний та поведінковий. Представимо розподіл відповідей досліджуваних (спортсменів та любителів) за рівнями вираженості компонентів структури невербального спілкування (табл. 3).

У досліджуваних досить розвинені навички невербального спілкування. У спортсменів-дзюдоїстів спостерігаємо високий рівень розвиненості когнітивного $(75 \%)$, емоційного $(80,3 \%)$ та поведінкового $(87,7 \%)$ показників невербального спілкування. У дзюдоїстів-любителів вказані компоненти розвинені посередньо $(62,3 \%$ - когнітивний, $41,3 \%$ - емоційний та $64 \%$ - поведінковий складники), що, ймовірно, пов'язано зі специфікою та інтенсивністю спортивної діяльності обох досліджуваних груп.

Згідно 3 результатами кореляційного аналізу отримано тісні кореляційні співзв'язки на рівнях статистичної значимості 0,05 та 0,01 ; зокрема, рівень процесів збудження кореляційно пов'язаний 3 такими шкалами невербального спілкування, як: гучність голосу $(0,746)$, темп мовлення $(0,765)$, образність мовлення $(0,729)$, інтонація $(0,798)$, рухова активність $(0,591)$, міміка $(0,641)$, когнітивний компонент невербального спілкування $(0,677)$, емоційний компонент невербального спілкування $(0,577)$ та поведінковий компонент невербального спілкування $(0,616)$. 
Таблиця 3

Рівні вираженості компонентів невербального спілкування досліджуваних

\begin{tabular}{|c|l|c|c|c|c|}
\hline \multirow{2}{*}{ № } & \multirow{2}{*}{$\begin{array}{c}\text { Компоненти } \\
\text { невербального } \\
\text { спілкування }\end{array}$} & \multicolumn{2}{|c|}{ Спортсмени-дзюдоїсти } & \multicolumn{2}{|c|}{ Любителі } \\
\cline { 3 - 6 } & \multicolumn{1}{|c|}{$\begin{array}{c}\text { Середній бал } \\
\text { Відсоток } \\
\text { вираженості* }\end{array}$} & Середній бал & $\begin{array}{c}\text { Відсок } \\
\text { вираженості }\end{array}$ \\
\hline 2 & когнітивний & 22,5 & $75 \%$ & 18,7 & $62,3 \%$ \\
\hline 3 & пмоційний & 24,1 & $80,3 \%$ & 12,4 & $41,3 \%$ \\
\hline
\end{tabular}

* позначає відсоток від максимального показника; максимальний бал - 30 б.

Рівень процесів гальмування кореляційно пов’язаний $з$ такими шкалами невербального спілкування, як: гучність голосу $(0,810)$, темп мовлення $(0,594)$, образність мовлення $(0,840)$, збій мовлення $(0,554)$, інтонація $(0,620)$, рухова активність $(0,388)$, міміка $(0,788)$, когнітивний компонент невербального спілкування $(0,694)$, емоційний компонент невербального спілкування $(0,788)$ та поведінковий компонент невербального спілкування $(0,641)$.

Шкала рухливості нервових процесів кореляційно пов'язана 3 такими шкалами невербального спілкування, як: гучність голосу (0,554), темп мовлення $(0,620)$, образність мовлення $(0,611)$, збій мовлення $(0,594)$, інтонація $(0,840)$, рухова активність $(0,611)$, міміка $(0,694)$.

Врівноваженість по силі кореляційно пов'язана 3 такими шкалами невербального спілкування, як: гучність голосу $(0,798)$, темп мовлення $(0,388)$, збій мовлення $(0,729)$, інтонація $(0,583)$, міміка $(0,632)$.

Тож можемо сказати, що характеристики темпераменту тісно пов'язані зі спортивною продук- тивністю досліджуваних спортсменів-дзюдоїстів. Далі встановимо, чи існують статистично значимі відмінності за групами досліджуваних (спортсмени-професіонали та любителі), щоб виявити, чи існують відмінності у зв'язках темпераменту, невербального спілкування та спортивної діяльності (у нашому випадку - професійних схильностей дзюдоїстів, тобто таких якостей, які чинять вплив і дозволяють якісно здійснювати спортивну діяльність на рівні професіонала).Зведені результати, отримані в ході аналізу відмінностей між групами досліджуваних, представлено в табл. 4.

Отже, майже всі виділені показники мають статистично значимі відмінності по групах досліджуваних осіб: спортсменів-дзюдоїстів та любителів. Зокрема, статистично значимі відмінності було відзначено за такими показниками, як: рівень процесів збудження ( $\mathrm{p}=3,29, \mathrm{r}=0,01)$, рівень процесів гальмування збудження $(\mathrm{p}=3,17$, $\mathrm{r}=0,01)$, рухливість нервових процесів збудження $(\mathrm{p}=2,89, \mathrm{r}=0,05)$, врівноваженість по силі $(\mathrm{p}=4,91, \mathrm{r}=0,01)$, темп мовлення $(\mathrm{p}=2,68$,

Таблиця 4

Статистично значимі відмінності між групами досліджуваних, за t-критерієм Стьюдента

\begin{tabular}{|l|c|c|}
\hline \multicolumn{1}{|c|}{ Досліджуваний показник } & $\begin{array}{c}\text { Оцінка за т-кри- } \\
\text { терісм Стьодета }\end{array}$ & $\begin{array}{c}\text { Наяність/відсутність статистично } \\
\text { значимих відмінностей }\end{array}$ \\
\hline Рівень процесів збудження & 3,29 & наянні \\
\hline Рівень процесів гальмування & 3,17 & наявні \\
\hline Рухливість нервових процесів & 2,89 & наявні \\
\hline Врівноваженість по силі & 4,91 & відсутні \\
\hline Гучність голосу & 1,71 & наявні \\
\hline Темп мовлення & 2,68 & наявні \\
\hline Образність мовлення & 3,11 & наявні \\
\hline Збій мовлення & 3,39 & відсутні \\
\hline Інтонація & 1,02 & відсутні \\
\hline Рухова активність & 1,92 & наявні \\
\hline Зайві рухи & 2,79 & наявні \\
\hline Міміка & 3,84 & наявні \\
\hline Не диференційована за шкалами експресія & 2,97 & наявні \\
\hline Когнітивний КНС & 3,51 & наявні \\
\hline Емоційний КНС & 2,79 & наявні \\
\hline Поведінковий КНС & 2,30 & \\
\hline
\end{tabular}

* КНС - компонент невербального спілкування 
$\mathrm{r}=0,05)$, образність мовлення ( $\mathrm{p}=3,11, \mathrm{r}=0,01)$, збій мовлення $(\mathrm{p}=3,39, \mathrm{r}=0,01)$, зайві рухи $(\mathrm{p}=2,79, \mathrm{r}=0,05)$, міміка $(\mathrm{p}=3,84, \mathrm{r}=0,01)$, не диференційована за шкалами експресія $(\mathrm{p}=2,97$, $\mathrm{r}=0,05)$, а також когнітивний $(\mathrm{p}=3,51, \mathrm{r}=0,01)$, емоційний $(\mathrm{p}=2,79, \mathrm{r}=0,05)$ і поведінковий $(\mathrm{p}=1,30, \mathrm{r}=0,05)$ компоненти невербального спілкування. Не було відзначено статистично значимих відмінностей за показниками гучності голосу, інтонації та рухової активності.

Заключним етапом стало надання описової характеристики кожного типу темпераменту за невербальними проявами. Отже, згідно з результатами нашого дослідження проаналізуємо, особам $з$ яким типом темпераменту найбільш притаманні відповідні невербальні прояви.

Згідно $з$ типологією Я. Стреляу, залежно від особливостей такої взаємодії та превалювання одного механізму реагування над іншим у загальному процесі психічного реагування формуються свої поведінкові особливості, що відрізняються типологічно [8].

Комбінування трьох процесів (збудження, гальмування та рухливість) і особливостей функціонування нервової системи та їх кількісне вираження в методиці Я. Стреляу дозволяє послідовно аналізувати темперамент, відносячи його до певних умовних типів: сильний - слабкий, типологічно розділяючи енергетичні можливості психіки оптимально реагувати і функціонувати у власних кордонах між мінімальним порогом збудження, перевищення якого «включає» здатність реагування, і граничним порогом, за яким вплив перевищує можливості психіки реагувати адекватно реагувати або, взагалі, включаючи механізми позамежного гальмування.

Рухливість психічних процесів формує свої оптимальні умови психічного реагування і формує свій тип темпераментних особливостей i свою стратегію поведінки [7]. Інертність психічних процесів потребує своїх оптимальних умов, i загальний процес психічного реагування приймає вигляд своїх типологічних особливостей, що й особливим чином виражається в поведінці.

Сильний тип темпераменту поділяється на врівноважений і неврівноважений. У врівноваженого типу темпераментного реагування механізми збудження і гальмування в загальному процесі психічного реагування значимо збалансовані й виражаються в поведінці як свій комплекс особистісних умов, засобів і можливостей життєдіяльності [10].

Згідно 3 результатами нашого дослідження, у спортсменів-дзюдоїстів, яким притаманний сильний врівноважений тип темпераменту, невербальні прояви у спілкуванні виражаються в помірних мімічних проявах та руховій актив- ності, оптимальній гучності та інтонації голосу, помірному темпі мовлення, вираженій образності мовлення тощо.

У неврівноваженого типу механізми збудження превалюють над механізмами гальмування, що й у поведінці виражається як особлива стійка система життєдіяльності зі своїми особливими умовами, засобами і можливостями.

Виходячи 3 отриманих результатів, пропонуємо під час роботи зі спортсменами-дзюдоїстами активувати психологічну роботу за такими ключовими напрямами (рис. 6):

Результати нашого емпіричного дослідження дозволили встановити, що серед групи спортсменів-дзюдоїстів немає досліджуваних, які мають сильний неврівноважений тип темпераменту та характеризуються такими особливостями, як висока рухова активність та мімічні прояви (іноді надмірні), яскрава образність мовлення, сильна інтонаційна вираженість та темпові особливості, можливість збоїв мовлення й також зайвих рухів унаслідок надмірної жестикуляції та ін.

Сильний тип темпераментного реагування, що володіє особливостями врівноваженої взаємодії механізмів збудження і гальмування в загальному процесі психічного реагування, також має модифікаційні особливості, відбивається в поведінці й формується механізмами рухомого або інертного психічного реагування [9].

Слабкий тип темпераменту, згідно з результатами нашого дослідження, визначає такі невербальні прояви, як: низька інтонаційна і темпоритмова вираженість та гучність голосу, слабка образність мовлення, слабка рухова активність та мімічні прояви, можливі зайві рухи.

Висновки та перспективи подальших досліджень. Результати аналізу темпераментальних особливостей спортсменів-дзюдоїстів порівняно 3 неспортсменами (любителями, які займаються дзюдо на рівні новачка) показали такі особливості: в осіб, яким притаманний сильний врівноважений тип темпераменту, невербальні прояви у спілкуванні виражаються в помірних мімічних проявах і руховій активності, оптимальній гучності та інтонації голосу, помірному темпі мовлення, вираженій образності мовлення тощо.

Дослідження дозволили встановити, що спортсмени-дзюдоїсти, які мають сильний неврівноважений тип темпераменту, характеризуються такими особливостями, як висока рухова активність та мімічні прояви (іноді надмірні), яскрава образність мовлення, сильна інтонаційна вираженість та темпові особливості, можливість збоїв мовлення й також зайвих рухів унаслідок надмірної жестикуляції та ін. Слабкий тип темпераменту спортсмена-дзюдоїста 


\section{Напрями психологічної підготовки спортсмена- дзюдоїста}

1 - формування функціональної надійності психіки спортсмена, що досягається на основі удосконалення спеціалізованих форм пізнавальної діяльності. У результаті формуються спеціальні знання, практичні вміння і навички, специфічний руховий досвід.

2 - формування емоційно-вольової стійкості, психологічної надійності спортсмена. Це передбачає розвиток здатності контролювати свою поведінку в екстремальних ситуаціях спортивної діяльності, ефективно діяти під час змагань.

3 - формування психічної готовності до змагань в умовах міжособистісного і групового суперництва. Тут важливо своєчасно психологічно адаптуватися до мінливих обставин змагальної боротьби, подолання психологічних бар'єрів суб'єктивного порядку, знання сильних і слабких сторін суперника, його тактики тощо.
4 - досягнутий на змаганнях результат і особливості
післязмагальної діяльності. Особливо це актуально в ситуації, коли спортсмен закінчує спортивну кар'єру, активні заняття спортом і потребує підтримки оптимального рівня психічної робочої властивості, адаптації до нових умов діяльності.

\section{Рис. 6. Основні напрями та принципи психологічної підготовки спортсменів-дзюдоїстів}

визначає такі невербальні прояви, як: низька інтонаційна і темпоритмова вираженість і гучність голосу, слабка образність мовлення, слабка рухова активність та мімічні прояви, можливі зайві рухи.
Подальші дослідження можуть бути спрямовані на поглиблення наукового аналізу щодо залежності спортивної результативності дзюдоїстів-професіоналів від особливостей темпераменту та емоційних аспектів поведінкових проявів.

\section{ЛITЕРАТУРА}

1. Batista, M., Castuera, R. J., Honório, S., Petrica, J., \& Serrano, J. (2016). Self-determination and life satisfaction: An exploratory study with veteran judo athletes. Revista de Artes Marciales Asiáticas, 11(2s), 90-91.

2. Burikov, A. V., \& Yaroslavl Higher Military School of Air Defense of the Ministry of Defence of the Russain Federation. (2018). Peculiarities of psychological training of sportsmen. A Breakthrough in Science: Development Strategies. TSNS Interaktiv Plus.

3. Delrue, J., Soenens, B., Morbée, S., Vansteenkiste, M., \& Haerens, L. (2019). Do athletes' responses to coach autonomy support and control depend on the situation and athletes' personal motivation?. Psychology of sport and exercise, 43, 321-332.

4. Gillet, N., Vallerand, R. J., Amoura, S., \& Baldes, B. (2010). Influence of coaches' autonomy support on athletes' motivation and sport performance: A test of the hierarchical model of intrinsic and extrinsic motivation. Psychology of sport and exercise, 11(2), 155-161. 
5. Korobeynikov, G. V., Korobeynikova, L. G., Romanyuk, L. V., Dakal, N. A., \& Danko, G. V. (2017). Relationship of psychophysiological characteristics with different levels of motivation in judo athletes of high qualification. Pedagogics Psychology Medical-Biological Problems of Physical Training and Sports, 21(6), 272.

6. Schmid, M. J., Charbonnet, B., Conzelmann, A., \& Zuber, C. (2021). More success with the optimal motivational pattern? A prospective longitudinal study of young athletes in individual sports. Frontiers in psychology, 11, 4062.

7. Sérgio, L. C. dos S., Luiz, F. C. J., Miguel, A. T., \& Jose, L. L. L. (2017). Olympic and world champion judo athletes: Motivational aspects. Journal of Physical Education and Sport Management, 8(2), 24-31.

8. Serpell, B. G., Strahorn, J., Colomer, C., McKune, A., Cook, C., \& Pumpa, K. (2018). The effect of speed, power and strength training, and a group motivational presentation on physiological markers of athlete readiness: A case study in professional rugby. International Journal of Sports Physiology and Performance, 14(1), 1-15.

9. Sterkowicz-Przybycien, K., Blecharz, J., \& Sterkowicz, S. (2017). Motivation in judo: rethinking the changes in the European society. Archives of Budo, 13, 227-234.

10. Zienius, M., Skarbalius, A., Zuoza, A. K., \& Pukènas, K. (2018). Peculiarities of pre-competitive psychological factors, sport performance indicators and physiological demands in youth golf. Baltic Journal of Sport \& Health Sciences, 2(93). doi:10.33607/bjshs.v2i93.119 